\title{
Contamination of food with cadmium and dioxins - influence on the human body*
}

\section{Zanieczyszczenia żywności kadmem i dioksynami - wpływ na organizm człowieka}

\author{
Aleksandra Słojewska, Izabela Gutowska ${ }^{凶}$ \\ Pomorski Uniwersytet Medyczny w Szczecinie, Katedra i Zakład Żywienia Człowieka i Metabolomiki,, ul. Broniewskiego 24, 71-460 Szczecin \\ Pomeranian Medical University in Szczecin, Department of Human Nutrition and Metabolomic \\ $\triangle$ gutowska@pum.edu.pl
}

\begin{abstract}
Introduction: Food is a carrier of many pollutants nowadays. For cadmium and dioxins, it is the main source of these compounds in the general population.

Hence, the aim of this work was to collect data on the health effects associated with exposure to cadmium and dioxins which get into the human body through food.

Materials and methods: A literature review was conducted by searching the scientific Medline database (PubMed) and Google Scholar.

Results: Health effects associated with a long-term exposure to low doses of cadmium and dioxins may be nonspecific and are rarely attributed to food sources. These may cause disorders affecting hormonal balance, kidney function, lipid metabolism,
\end{abstract}

fertility, cognitive function, bone mineralization, and susceptibility to diseases and allergies. These compounds may also lead to cancer development.

Conclusions: The general population faces the problem of longterm exposure to small doses of these substances due to their accumulation in the body, even if their amounts do not exceed the relevant standards. The health effects of this type of exposure may be significantly delayed and are not likely to be attributed to the consumption of contaminated food. Consumers wishing to reduce the amounts of these compounds delivered to the body should limit the consumption of grilled and smoked products, and should also opt for organic food.

Keywords: cadmium; dioxins; food contamination.

\begin{abstract}
ABSTRAKT
Wstęp: Żywność jest obecnie nośnikiem wielu zanieczyszczeń. Dla populacji ogólnej stanowi ona główne źródło kadmu oraz dioksyn.

Celem pracy było zebranie danych dotyczących skutków zdrowotnych związanych z ekspozycją na kadm oraz dioksyny, które mogą dostawać się do organizmu człowieka razem z żywnością. Materiały i metody: Dokonano przeglądu piśmiennictwa wybranego z naukowej bazy danych Medline (PubMed) oraz wyszukiwarki Google Scholar.

Wyniki: Skutki zdrowotne związane z długotrwałą ekspozycją na niewielkie dawki kadmu oraz dioksyn mogą być niespecyficzne i rzadko kojarzone ze spożywaniem żywności. Zaburzenia mogą dotyczyć gospodarki hormonalnej, nefropatii, metabolizmu
\end{abstract}

lipidów, płodności, funkcji poznawczych, mineralizacji kości czy zwiększonej podatności na choroby i alergie. Omawiane związki mogą być przyczyną rozwoju nowotworów.

Wnioski: W populacji ogólnej problemem jest długotrwałe narażenie na niewielkie dawki kadmu oraz dioksyn ze względu na ich kumulację w organizmie, nawet jeśli ich ilości nie przekraczają określonych norm. Skutki zdrowotne tego typu ekspozycji mogą być odległe w czasie i rzadko kojarzone ze spożyciem zanieczyszczonej żywności. Konsumenci chcący zmniejszyć ilość tych związków dostarczanych do organizmu powinni ograniczyć spożywanie grillowanych i wędzonych produktów, a także wybierać żywność ekologiczną.

Słowa kluczowe: kadm; dioksyny; zanieczyszczenia żywności.

\section{INTRODUCTION}

Today, food may carry many substances potentially harmful to human health. Continuous contamination of the environment by the steadily growing food industry means that it is practically impossible to produce food free of any pollutants. Many substances generated by industrial plants and factories are quite persistent and accumulate in the soil. From there they may be absorbed by plants and in this way enter the food chain. The growing global population and economic progress require measures aimed at increasing the productivity of crop and animal production. These entail the use of various plant protection products, fertilisers, antibiotics and veterinary medication, the residues of which are not without influence

\footnotetext{
* This article is based on the bachelor's thesis by Aleksandra Słojewska entitled "The influence of food contamination on the human body" defended at the Faculty of Health Sciences of the Pomeranian Medical University in Szczecin. Thesis supervisor: dr hab. n. zdr. prof PUM Izabela Gutowska. The original comprises: 62 pages, 2 tables, 167 literature items.
} 
on animal and human health. Moreover, food may be additionally contaminated at any single stage of processing, between the field and the plate, ultimately leading to the accumulation of various toxic compounds and metals in the body.

In today's world, apart from substances occurring naturally, food may contain all kinds of foreign matter. Pursuant to the Act on Sanitary Requirements for Food and Nutrition (Polish Journal of Laws 1970 item 245), this term refers to all substances which fail to meet the criteria of food product or stimulants and are present in the food or on the surface. They may include food additives, as well as contaminants and chemicals used in plant cultivation or protection. Among the contaminants, an important role is played by various combustion process by-products from organic matter, including dioxins [1] and cadmium [2], which have been identified in foods of both plant and animal origin.

\section{CADMIUM CONTAMINATION IN FOOD}

\section{Characteristics and sources of cadmium in the environment}

Cadmium is a heavy metal which represents a major threat to animals, plants and humans alike. It is one of the most toxic of metals [3]. Both cadmium and cadmium compounds are classified by the International Agency for Research on Cancer (IARC) as group 1 carcinogens (proven to be carcinogenic to humans) [4]. Since foodstuffs are the main source of human intake of the metal, its content in respective food products is limited and subject to official controls. Pursuant to the European Commission Regulation (EC) 1881/2006, the maximum levels of cadmium are $0.05^{-0.5} \mathrm{mg} / \mathrm{kg}$ wet weight (w.w.), depending on product category, and the provisional tolerable weekly intake (PTWI) is $7 \mu \mathrm{g} / \mathrm{kg}$ body weight (b.w.) [5].

Cadmium is not very common in natural conditions, but mainly due to the extraction of raw materials from the earth's crust, it is released into the environment. Cadmium emissions originate principally from lead-zinc ores, zinc and lead smelting, galvanising plants and fossil fuel combustion processes, e.g. coal [2]. The metal has numerous applications in many different industries, polluting water as well as soil and air. It does not undergo degradation and has a long half-life, so once introduced, it remains in the environment for many years [6].

Plants are capable of absorbing cadmium from the soil and air. The rate of uptake depends, however, on the type of plant and the bioavailability of cadmium in the soil. In alkaline environments, cadmium absorption is low as it exists in complexed form in sparingly soluble hydroxides and carbonates, unavailable to cells. A similar effect is produced by the presence of chelators in the soil. In neutral $\mathrm{pH}$ soils, the prevalent form is free $\mathrm{Cd}^{2+}$ ions, which are readily absorbed by transmembrane transporters of minerals essential for plant growth, i.e. of potassium, iron, calcium or magnesium. That is why their uptake depends on soil concentrations of these minerals and also salinity. Upon absorption, cadmium is transported to the upper sections of the plant and permanently bound in cells. Accumulation takes place mainly in leaves, fruits and storage organs. In this way, cadmium enters the food chain and, once ingested, continues to accumulate in animal and human tissues $[7,8]$.

\section{Cadmium in food}

A certain amount of cadmium is found in most foodstuffs, but plant products are its main source. Cereals as well as fruit and vegetables together account for approximately $75 \%$ of total consumption. Plants such as tobacco, naturally accumulate large amounts of cadmium include root and leaf vegetables, i.e. lettuce, spinach, celery and cabbage. Relatively low cadmium levels are found in potato tubers, corn, beans and peas. Cadmium is also present in milk, meat products and fish. Among animal products, the highest cadmium levels are observed in molluscs and crustaceans $[9,10]$. Cereals, meat products, potatoes and other vegetables provide the highest quantities of cadmium in the diet of Polish people [11]. High amounts of cadmium may be found in cocoa and its products, e.g. chocolate or other sweets [12].

In Poland, dangerously high levels of cadmium in foodstuffs, exceeding permissible limits, are a relatively rare phenomenon, as confirmed by analyses carried out by independent research facilities as well as low numbers of notifications from the early warning system (Rapid Alert System for Food and Feed RASFF) $[12,13,14]$. In 2017, only 2 such cases were recorded, with cadmium levels exceeding the maximum limits in carrots grown domestically and cocoa brought in from Ecuador. A similar number of alerts occurred in 2016, and all of them were related to the migration of dangerous amounts of cadmium from decorative glass containers imported from China [14].

Lower amounts of heavy metals, including cadmium, are found in organic food, with the differences most pronounced for potatoes and cereals [15].

In Poland, the consumption of cadmium compounds in food by adults ranges between $23-120 \mu \mathrm{g} /$ day, which corresponds to $29-45 \%$ of the provisional tolerable weekly intake. In different areas of the world, the intake ranges $25-200 \mu \mathrm{g} /$ day $[16,17]$.

\section{Metabolism and the impact on the human body}

While even small doses of cadmium have a toxic effect on the body, acute cadmium poisoning is very rare and largely associated with occupational exposure to airborne cadmium. Chronic poisoning is much more common and tends to remain asymptomatic for a long time. The initial manifestations of cadmium poisoning may be non-specific, manifesting as malaise, loss of appetite, or a metallic taste and dryness in the mouth [6]. The best-known documented example of a mass poisoning was in Toyama Prefecture, Japan, where cadmium-contaminated wastewater from mines was released into a river and used to irrigate the local rice fields. Consumption of the contaminated rice induced symptoms including nephropathy, joint pain and frequent bone fractures. The condition was very painful and therefore given the name Itai-Itai (from the Japanese word itai, which means "severe pain") $[2,18]$.

Cadmium can enter the human body by ingestion, inhalation or through the skin [9]. Absorption from the gastrointestinal 
tract is quite low, approx. $3-8 \%$ of the oral intake, with most of the uptake taking place already in the duodenum. The absorption rate is influenced by the dietary content of protein, fibre and divalent ions of such elements as zinc, copper, calcium and iron, as well as individual characteristics, like sex and age. The higher the dietary intake of additional metals, the lower the cadmium intake from the lumen, because of the ions competing for transport by proteins, like metal transporter protein 1 (MTP1), divalent metal transporter 1 (DMT1), zinc transporters hZTL1 and ZNT1, as well as calcium channels [19]. As $\mathrm{Cd}^{2+}$ ions have the same high affinity to DMT1 as $\mathrm{Fe}^{2+}$, their uptake depends on the body's stores of iron. When these are depleted, iron transmembrane transporters are upregulated, which results in increased absorption of both $\mathrm{Fe}^{2+}$ and $\mathrm{Cd}^{2+}$ ions. The relationship between cadmium absorption and the body's levels of other minerals, e.g. zinc, is similar [19, 20]. It is now known that cadmium in the gastrointestinal tract is mostly bound to metallothionein (CdMT) or phytochelatin (CdPC), as a result of chelating defensive mechanisms used by plants against the toxic effects of heavy metals [20, 21]. They are absorbed via transcytosis mediated by the human neutrophil gelatinase-associated lipocalin (hNGAL) receptor in the cells of the colon [22].

After passing through the enterocyte membrane, cadmium is gradually released into the bloodstream, where the majority is transported bound to the erythrocyte membrane or haemoglobin. The remainder is associated with albumins and thiol (-SH) groups of cysteine and glutathione [17]. Via the hepatic portal system, it then gets into the liver, which is the first organ coming into contact with it. In response, its cells increase metallothionein synthesis, binding $\mathrm{Cd}^{2+}$ ions into CdMT complexes. In this form, they are less toxic and can be sequestered, transported or excreted. The mechanism may be insufficient, though, and the complexes may be released into the bloodstream, ending up in various tissues and organs [23]. As kidneys work to filter the CdMT complexes and excrete them with urine, the proximal tubules are specifically prone to damage. This is because during this process, free $\mathrm{Cd}^{2+}$ ions are released again and most of them accumulate in the tubules, reducing the glomerular filtration rate (GFR) and increasing glomerular permeability, and in severe cases even leading to chronic kidney disease [20,24].

As any absorbed cadmium is excreted very slowly, it gradually accumulates in tissues. It is estimated that as little as $0.01 \%$ of the intake is removed from the body [10]. Kidneys and the liver are the main organs to be affected by cadmium toxicity, because this is where the highest accumulation occurs. Aboveaverage amounts are also deposited in the intestine, pancreas, lungs, testicles and the central nervous system. After prolonged exposure, cadmium also accumulates in bones and hair. Inside cells, cadmium binds to numerous proteins of the cytoplasm, nucleus, mitochondrial and lysosomal membranes, in other words it does not have a specific accumulation target. It was demonstrated that the total body content of cadmium on average amounts to 15-30 mg and increases with age $[17,19]$. Body distribution depends on the form of cadmium and route of exposure.
Accumulation in the liver, kidneys and the intestine tends to be greater following exposure to $\mathrm{CdCl}_{2}$ rather than CdMT [19].

One of the toxic effects of cadmium is that it induces the formation of reactive oxygen species (ROS), e.g. hydroxyl radical or hydrogen peroxide, exacerbating oxidative stress in cells. It involves alterations of the mitochondrial membrane permeability and disruption of oxidative phosphorylation. It is associated with reduced concentrations of reduced glutathione in cells, which directly binds $\mathrm{Cd}^{2+}$ ions. Glutathione is a crucial antioxidant, which either interacts directly with ROS or participates as a co-factor to neutralize them. Too much oxidative stress is highly harmful to cells. Excessive amounts of ROS cause damage to proteins and lipids, which affects enzyme function and gene expression. It can also cause lipid peroxidation of polyunsaturated fatty acids in cellular membranes, disrupting their integrity and biological function [17].

The testicles are particularly sensitive to oxidative stress, hence cadmium is linked to adverse effects on the male reproduction system. It induces inflammatory response, damaging the vascular endothelium and reproductive cells. Damage also extends to the proteins responsible for the formation of gap junctions (including N-cadherins and connexin-43). Histopathological alterations are also visible, with apparent interstitial oedema and necrosis of seminiferous tubules. This leads to decreased testosterone synthesis and impaired spermatogenesis, undermining male fertility [10].

Cadmium also has an adverse effect on the skeletal system, as in the above-mentioned Itai-Itai disease. It replaces calcium ions in bone tissue, leading to bone demineralisation, osteomalacia and, eventually, osteoporosis. These effects may be exacerbated by systemic deterioration of divalent ion metabolism, as well as impaired absorption of calcium from the intestine. Additionally, cadmium inhibits the activity of 1-hydroxycholecalciferol hydroxylase - a mitochondrial enzyme from the cytochrome (CYP) family, responsible for the biosynthesis by kidney of biologically active vitamin $\mathrm{D}_{3}-1,25(\mathrm{OH})_{2} \mathrm{D}_{3}$. The vitamin is a pleiotropic hormone whose actions include regulation of calcium homeostasis and control of bone cell differentiation $[25,26]$.

Cadmium is classified as a group 1 carcinogen, which means it is known to induce neoplastic processes [4]. The exact mechanism of cadmium carcinogenesis is not yet fully known, but DNA changes have been consistently observed in in vitro studies as a result of the indirect effects of cadmium on increasing oxidative stress. It is presumed to inhibit the activity of DNA repair enzymes as well. Other hypotheses suggest that apoptotic resistance is acquired as a result of exposure to cadmium compounds. New studies have shown that cadmium is capable of changing the conformation of E-cadherin, a transmembrane $\mathrm{Ca}^{2+}$-binding glycoprotein which plays an important role in cellcell adhesions, especially in epidermal cells. Functional changes in these proteins not only destroy intercellular connections, but also lead to uncontrolled proliferation and disrupt apoptosis, which is a well-known mechanism in tumour formation $[17,26]$.

Current research focuses on the influence of heavy metals on the hippocampus, which appears to be the target in 
terms of their negative effect on cognitive function. Karri et al. conducted a study in which they confirmed that cadmium, alongside metallic mercury, arsenic and lead, induces cytotoxic, genotoxic, and apoptotic effects on the HT-22 hippocampal cell line [27].

It has also been reported that cadmium may affect lipid metabolism, even though the exact mechanism of this effect requires further study. It was demonstrated that exposure of mice to subchronic doses of $\mathrm{CdCl}_{2}(10-100 \mathrm{mg} / \mathrm{L})$ caused a significant elevation in the levels of Fasn and $S c d-1$ genes that participate in hepatic fatty acid synthesis. The expression of genes responsible for fatty acid uptake by hepatocytes and hepatic lipoprotein lysis was upregulated, too. Despite these changes at the cellular level, the development of obesity, insulin resistance or hepatic lipid accumulation in the mice was not observed [28]. On the other hand, zebrafish (Danio rerio) exposed to $\mathrm{CdCl}_{2}$ concentrations of 5 and $25 \mu \mathrm{g} \mathrm{Cd} / \mathrm{L}$ for 30 days showed elevated hepatic lipid accumulation, increased expression and activity of enzymes related to lipid metabolism (like fatty acid synthase - FAS, 6-phosphogluconate dehydrogenase - 6PGD, glucose 6-phosphate dehydrogenase - G6PD, and malic enzyme - ME), as well as increased expression level of genes involved in mitochondrial degradation - mitophagy. To explain these findings, the authors suggested that oxidative stress (via ROS) and mitochondrial dysfunction mediate the Cd-induced disorder of lipid metabolism [29].

\section{DIOXIN CONTAMINATION IN FOOD}

\section{Characteristics and sources of dioxins in the environment}

Dioxin is an umbrella term for 75 polychlorinated dibenzo-pdioxin (PCDD) congeners and 135 polychlorinated dibenzofuran (PCDF) congeners - a group of 200+ aromatic compounds with similar structures and physico-chemical properties. They can have adverse effects on human health even in minimal concentrations in the range of $10^{-12} \mathrm{~g}$ [30]. The congeners with 4-6 chlorine atoms in their molecules are particularly dangerous, and the most toxic dioxin is 2,3,7,8-tetrachlorodibenzo-p-dioxin (TCDD) [30]. This dioxin, like cadmium and cadmium compounds, is recognised by IARC as a group 1 carcinogen [31, 32].

Dioxins have a lipophilic nature, which means they dissolve well in fats and organic solvents. Their solubility goes up with increasing numbers of chlorine atoms in the benzene rings. Similar properties are exhibited by 12 polychlorinated biphenyl congeners, known as dioxin-like compounds (dl-PCB), which are often described together because of the similar mechanism of toxicity [31]. Individual dioxins and dl-PCB vary widely in toxicity, so to determine the total toxicity of a mixture of compounds (toxic equivalency - TEQ), it is necessary to refer to the toxic equivalency factors (TEF) attributed to the respective congeners. The toxic equivalency factors describes the toxicity of the given congener in relation to TCDD, whose TEF $=1$, while TEQ is the figure resulting from the multiplication of the concentration and individual TEF values of each congener [33].
Dioxins arise in all combustion processes of organic matter containing even small amounts of chlorinated compounds. Uncontrolled combustion of industrial waste and household waste is currently regarded as the primary source of dioxin emissions [1]. They are also formed in vehicle engines during the combustion of unleaded or leaded petrol containing chlorine derivatives [34]. Dioxins may also arise as a by-product in the chemical industry, e.g. in the production of organochlorine pesticides. Natural dioxin emissions result from fire accidents. Dioxins contaminate water, soil and air. Because of their persistence, they are slow to break down and instead accumulate in the environment and living organisms [31].

\section{Dioxins in food}

It is estimated that food accounts for approx. 90\% of the overall dioxin intake [34]. In the diet of Polish people, approx. 59\% of dietary intake of dioxins comes from meat and eggs, and $35 \%$ from milk and dairy products. The highest concentrations of these compounds are found in fish and fish products including fish oil, but because of their low consumption they only account for some $6 \%$ of the overall intake [35].

In 2002-2006, a study was undertaken to evaluate the content of dioxins and dl-PCB in Baltic fish caught in the Polish fishing zones. Dioxin levels were analysed in 177 samples and only a few (less than 10) exceeded the applicable limits, which at that time amounted to $8 \mathrm{pg} / \mathrm{g}$ w.w. for PCDD/PCDF and dlPCB combined, and 4 pg/g w.w. for PCDD/PCDF $[35,36]$. Please note, however, that new stricter standards came into effect in January 2012, whereby the maximum total content of PCDD and dl-PCB was set at $6.5 \mathrm{pg} / \mathrm{g}$ w.w. [37]. Szlinder-Richert et al. obtained slightly different results in their study conducted in the same period and also focusing on the fish from the southern Baltic Sea. They found that standards were exceeded in $80 \%$ of salmon samples, approx. $16 \%$ of sprat samples, and approx. $3 \%$ of herring samples, mainly with respect to the levels of PCDF [38]. Importantly, southern areas of the Baltic Sea are less polluted by these compounds than the north, let alone the most polluted regions of the Gulf of Finland or the Gulf of Bothnia [35]. According to a note from 2007 available on the website of the National Institute of Hygiene (Państwowy Zakład Higieny), despite the presence of dioxins in fish fat, the health benefits associated with the consumption of the essential unsaturated fatty acids exceed the potential risks. Due to the special caution which needs to be exercised during pregnancy, breastfeeding and with young children, it is recommended that their diets do not include Baltic herring or salmon [39].

Very high levels of dioxins are found in grilled and smoked foods. Studies into dioxin levels in foods of animal origin identified their highest concentrations in butter, cheese and meat. Very low levels are found in plants but, if consumed in large quantities, they too may pose a certain threat. It is estimated that in countries where fruit and vegetables constitute a major food source, like in Spain or Italy, they may account for 12-20\% of the total intake $[31,35]$.

The tolerable daily intake (TDI) of dioxins amounts to $2 \mathrm{pg}$ WHO-TEQ/kg b.w., which corresponds to $140 \mathrm{pg} /$ day for 
a person weighing $70 \mathrm{~kg}$, while the weekly intake (TWI) for dioxins and dl-PCB is $14 \mathrm{pg}$ WHO-TEQ/kg b.w. It is estimated that the daily dietary intake of dioxins in the Polish population is approx. $117 \mathrm{pg}$ WHO-TEQ/d in summer months and approx. $80 \mathrm{pg}$ WHO-TEQ/d in the other months [31].

\section{Metabolism and the impact on the human body}

A large epidemiological study into the human health effects of dioxins was carried out by Consonni et al. following the disaster at Seveso, Italy, where a TCDD reactor exploded in 1976. It was the largest amount of TCDD ever to be released into the environment, in excess of $34 \mathrm{~kg}[40,41]$. The study included 287,108 participants. The highest number of deaths were caused by cancers of the lymphatic and haematopoietic tissue, but there were also reports of deaths due to rectum and lung cancers, circulatory diseases, chronic obstructive pulmonary disease, and diabetes. Reproductive and nervous system disorders, repeated infections, growth disorders and adverse effects on dentition were also observed [33].

Dioxins may enter the body through breathing contaminated air or skin contact, but the large part is ingested with food. Uptake is enhanced by the presence of fats, because dissolved dioxins are absorbed with them from the digestive system and transported to the liver and adipose tissue. Because of their properties, they are accumulated and the body burden of dioxins increases with age in people inhabiting dioxincontaminated areas [42].

In hepatocytes, both dioxins and dl-PCB bind to the cytosolic aryl hydrocarbon receptor (AhR) and activate it. The active complex translocates into the nucleus and binds to a specific DNA fragment. This initiates the biosynthesis of cytochrome P450 and P448 enzymes responsible, among others, for dioxin metabolism. The transformations involve hydroxylation, followed by acetylation or conjugation with glucuronic acid or glutathione. This renders them hydrophilic, which means they can be efficiently eliminated with urine [31]. The dioxin-AhR binding may also have other biological consequences. Sato et al. exposed mice to low doses of TCDD and demonstrated changes in the expression of genes involved in the circadian rhythm, cholesterol biosynthesis, fatty acid synthesis, and glucose metabolism in the liver [43].

Transformations of dioxins lead to the emergence of free radicals in cells, causing oxidative stress. This was confirmed in studies of TCDD exposure in rodents. Researchers observed increases in hepatic lipid peroxidation, increased hepatic and macrophage DNA damage, higher membrane permeability and decreased amounts of cellular glutathione and NADPH [44]. Oxidative stress also leads to the progression of inflammation, as evidenced by elevated levels of proinflammatory cytokines, particularly tumour necrosis factor (TNF), in animals following TCDD exposure. Some authors have linked the proinflammatory properties of dioxins with their toxic effect on the heart muscle and the central nervous system [42].

Dioxins are classified as so-called endocrine disruptors, i.e. compounds which alter normal endocrine function [35]. In their structure they mimic steroid hormones, like sex steroids and thyroid hormones, which means they can disrupt their synthesis, distribution and binding to the relevant receptors. As a result, a global dysregulation of release mechanisms may ensue [31]. Całkosiński et al. demonstrated reduced oestradiol levels and impaired fertility in female rats directly exposed to TCDD [45]. Changes were observed in their offspring, too, where females presented with increased oestradiol levels and males had reduced testosterone levels and impaired spermatogenesis. Other studies revealed that TCDD-induced changes in hormonal balance may adversely affect gonad differentiation and the development of secondary sexual characteristics [46].

Back in the 1990s, dioxins were demonstrated to produce immunotoxic effects, including thyroid involution, suppression of humoral and cell-mediated immune response and increased susceptibility of animal models to infectious diseases. A single dose of TCDD at $0.1,0.05$, or $0.01 \mu \mathrm{g} / \mathrm{kg}$ resulted in increased mortality among mice infected with an influenza virus, and when mice were exposed to doses of $0.005 \mu \mathrm{g} / \mathrm{kg}$ b.w. for 7 days, weakened immune response was observed [47]. The proposed mechanism behind the immunosuppressive effects of TCDD was its interaction with the Ah receptor, which was confirmed by Kerkvliet et al. [48]. TCDD also inhibits the maturation and differentiation of T-cells and B-cells, which are essential to cellular immunity and antibody production. It was shown to cause premature thymic involution. Additionally, a relationship was identified between the presence of TCDD in blood and low concentrations of immunoglobulin G (IgG). The immune system effects of dioxin exposure include the development of chloracne, a type of skin allergy. It is characterized mainly by epidermal hyperplasia and hyperkeratosis, as well as changes in the structure and function of sebaceous glands [31, 42].

Prenatal and neonatal exposure to TCDD is particularly critical, as the compound is capable of crossing the placenta and passing into the mother's milk. At this stage, dioxins can affect the development of the central nervous system, which may result in an abnormal formation of brain structures leading to behavioural changes. Rosińczuk et al. observed reduced mobility, apathy and significantly reduced food intake both in rats exposed to TCDD and their offspring. The results of the swimming test and the tail test showed an impaired motivation to swim and an extended response time [49].

Dioxins were demonstrated to be strongly associated with enamel defects, dental crown and root abnormalities and the increased incidence of neonatal teeth. In the study by Całkosiński et al. it was observed that the offspring of female rats exposed to TCDD had pulp chamber perforations, and symptoms in males included a thinner dentin layer, pulpal necrosis and poor enamel mineralisation [30].

\section{CONCLUSIONS}

Both cadmium and dioxin produce many undesirable effects in the body. Due to the establishment of permissible limits on the levels of these substances in food and quality control systems, acute intoxication events are relatively rare. Instead, 
the general population faces the problem of long-term exposure to small doses of these substances due to their accumulation in the body, even if the amounts do not exceed the relevant standards. The health effects of this type of exposure may be significantly delayed and are not likely to be attributed to the consumption of contaminated food. Consumers wishing to reduce the amounts of these compounds delivered to the body should limit the consumption of grilled and smoked products, and also opt for organic food.

\section{REFERENCES}

1. Szewczyńska M, Ekiert E, Pośniak M. Niekontrolowane procesy spalania jako źródła powstawania dioksyn i furanów. Bezp Pr Nauk Prakt 2006;1:8-11.

2. Mlynek V, Skoczyńska A. Prozapalne działanie kadmu. Post Hig 2005;59:1-8.

3. Ociepa-Kubicka A, Ociepa E. Toksyczne oddziaływanie metali ciężkich na rośliny, zwierzęta i ludzi. Inżynieria i Ochrona Środowiska 2012;15(2):169-80.

4. IARC Working Group on the Evaluation of Carcinogenic Risks to Humans Cadmium and cadmium compounds. Volume $100 \mathrm{C}$. A review of human carcinogens. IARC Monogr Eval Carcinog Risks Hum 2012;100(Pt C):121-45.

5. Commission Regulation (EC) No 1881/2006 of 19 December 2006 setting maximum levels for certain contaminants in foodstuffs, OJ 2006, L $364 / 5$ of 20.12 .2006

6. Czeczot H, Majewska M. Kadm - zagrożenie i skutki zdrowotne. Toksykologia 2010;66(4):243-50.

7. Kaczyńska A, Zajączkowski M, Grzybiak M. Toksyczny wpływ kadmu na rośliny i człowieka. Ann Acad Med Gedan 2015;45:65-70.

8. Smolders E. Cadmium uptake by plants. Int J Occup Med Environ Health 2001;14(2):177-83.

9. Krzywy I, Krzywy E, Peregud-Pogorzelski J, Łukasza K, Brodkiewicz A. Kadm - czy jest się czego obawiać? Ann Acad Med Stetin 2011;57(3):49-63.

10. Martynowicz H, Skoczyńska A, Kaczmarek-Wdowiak B, Andrzejak R. Wpływ kadmu na funkcję gonad męskich. Med Pr 2005;56(2):167-74.

11. Borawska MH, Socha K, Dziemianowicz M, Soroczyńska J. Dieta a zawartość kadmu i ołowiu w krwi pacjentów z chorobą Hashimoto. Bromat Chem Toksykol 2010;43(3):343-8.

12. Wojciechowska-Mazurek M, Starska K, Brulińska-Ostrowska E, Plewa M, Biernat U, Karłowski K. Monitoring zanieczyszczenia żywności pierwiastkami szkodliwymi dla zdrowia. Część I. Produkty zbożowe pszenne, warzywne, cukiernicze oraz produkty dla niemowląt i dzieci (rok 2004). Rocz Państ Zakł Hig 2008;59(3):251-66.

13. Pietrzak-Fiećko R, Bakuła S, Jakubowska D, Smoczyński SS. Zawartość kadmu i ołowiu w mleku spożywczym z wybranych regionów Polski. Environ Med 2013;16(3):15-9.

14. List of alerts on the risk related to food contamination. https://webgate. ec.europa.eu/rasff-window/portal/?event=searchResultList (24.09.2018).

15. Gadomska J, Sadowski T, Buczkowska M. Ekologiczna żywność jako czynnik sprzyjający zdrowiu. Probl Hig Epidemiol 2014;95(3):556-60.

16. Marzec Z, Łukasiewicz M. Kadm, ołów i nikiel w całodobowych racjach pokarmowych z placówek zbiorowego żywienia. Bromat Chem Toksykol 2010;43(3):281-6.

17. Czeczot H, Skrzycki M. Kadm - pierwiastek całkowicie zbędny dla organizmu. Post Hig 2010;64:38-49.

18. Horiguchi H, Teranishi H, Niiya K, Aoshima K, Katoh T, Sakuragawa N, et al. Hypoproduction of erythropoietin contributes to anemia in chronic cadmium intoxication: clinical study on Itai-itai disease in Japan. Arch Toxicol 1994;68(10):632-6.

19. Bonda E, Włostowsi T, Krasowska A. Metabolizm i toksyczność kadmu u człowieka i zwierząt. Kosmos. Problemy Nauk Biologicznych 2007;56(1-2):87-97.

20. Satarug S. Dietary cadmium intake and its effects on kidneys. Toxics 2018;6(1): pii: E15.

21. Li X, Zhang X, Wu Y, Li B, Yang Y. Physiological and biochemical analysis of mechanisms underlying cadmium tolerance and accumulation in turnip. Plant Diversity 2018;40(1):19-27.
22. Langelueddecke C, Lee WK, Thévenod F. Differential transcytosis and toxicity of the hNGAL receptor ligands cadmium-metallothionein and cadmium-phytochelatin in colon-like Caco-2 cells: Implications for in vivo cadmium toxicity. Toxicol Lett 2014;226(2):228-35.

23. Godt J, Scheidig F, Grosse-Siestrup C, Esche V, Brandenburg P, Reich A, et al. The toxicity of cadmium and resulting hazards for human health. J Occup Med Toxicol 2006;1:22.

24. Nomiyama K, Nomiyama H. Cadmium-induced renal dysfunction: New mechanism, treatment and prevention. J Trace Elem Exp Med 1998;11(2-3):275-88.

25. Hewison M, Zehnder D, Bland R, Stewart PM. 1alpha-Hydroxylase and the action of vitamin D. J Mol Endocrinol 2000;25(2):141-8.

26. Jin YH, Clark AB, Slebos RJ, Al-Refai H, Taylor JA, Kunkel TA, et al. Cadmium is a mutagen that acts by inhibiting mismatch repair. Nature Genet 2003;34(3):326-9.

27. Karri V, Kumar V, Ramos D, Oliveira E, Schuhmacher M. Comparative in vitro toxicity evaluation of heavy metals (lead, cadmium, arsenic, and methylmercury) on HT-22 hippocampal cell line. Biol Trace Elem Res 2018;184(1):226-39.

28. Zhang J, Wang Y, Fu L, Feng YJ, Ji YL, Wang H, et al. Subchronic cadmium exposure upregulates the mRNA level of genes associated to hepatic lipid metabolism in adult female CD1 mice. J App Toxicol 2018;38(7):1026-35.

29. Pan YX, Luo Z, Zhuo MQ, Wei CC, Chen GH, Song YF. Oxidative stress and mitochondrial dysfunction mediated Cd-induced hepatic lipid accumulation in zebrafish Danio rerio. Aquat Toxicol 2018;199:12-20.

30. Całkosiński I, Dobrzyński M, Cegielski M, Sieja A, Całkosińska M. Wielokierunkowe działanie 2,3,7,8-tetrachlorodibenzo-p-dioksyny (TCDD) na organizm ze szczególnym uwzględnieniem zmian w uzębieniu. Post Hig 2006;60:237-40.

31. Stec M, Kurzeja E, Kościołek A, Pawłowska-Góral K. Zagrożenia wynikające z narażenia na dioksyny i dioksynopodobne polichlorowane bifenyle. Probl Hig Epidemiol 2012;93(4):639-46.

32. IARC Working Group on the Evaluation of Carcinogenic Risks to Humans. Chemical agents and related occupations. Volume $100 \mathrm{~F}$. A review of human carcinogens. IARC Monogr Eval Carcinog Risks Hum 2012;100(Pt F):1-599.

33. Słowińska M, Koter-Michalak M, Bukowska B. Wpływ dioksyn na organizm człowieka - badania epidemiologiczne. Med Pr 2011;62(6):643-52.

34. Brzeski Z. Dioksyny i furany w środowisku i ich wpływ na organizm. Med Ogólna Nauki Zdr 2011;17(3):161-4.

35. Żukiewicz-Sobczak W, Chmielewska-Badora J, Krasowska E, Wojtyła A, Piątek J. Wpływ dioksyn na środowisko i organizm człowieka. Med Ogólna Nauki Zdr 2012;18(1):59-63.

36. Piskorska-Pliszczyńska J, Mikołajczyk S, Maszewski S, Warenik-Bany M, Baran M. Zawartość dioksyn w rybach z wybranych polskich rzek i jezior. Proc ECOpole 2013;7(2):685-93.

37. Commission Regulation (EU) No 1259/2011 of 2 December 2011 amending Regulation (EC) No 1881/2006 as regards maximum levels for dioxins, dioxin-like PCBs and non dioxin-like PCBs in foodstuffs, OJ 2011, L 320/18 of 3.12.2011.

38. Szlinder-Richert J, Barska I, Usydus Z, Ruczyńska W, Grabic R. Investigation of PCDD/Fs and dl-PCBs in fish from the southern Baltic Sea during the 2002-2006 period. Chemosphere 2009;74(11):1509-15.

39. Bezpieczeństwo żywności. http://www.pzh.gov.pl/bezpieczenstwozywnosci/ (24.09.2018).

40. Consonni D, Pesatori AC, Zocchetti C, Sindaco R, D'Oro LC, Rubagotti M, et al. Mortality in a population exposed to dioxin after the Seveso, Italy, accident in 1976: 25 years of follow-up. Am J Epidemiol 2008;167(7):847-58.

41. Di Domenico A, Cerlesi S, Ratti S. A two-exponential model to describe the vanishing trend of 2,3,7,8-tetrachlorodibenzodioxin (TCDD) in the soil at Seveso, northern Italy. Chemosphere 1990;20(10-12):1559-66.

42. Całkosiński I, Rosińczuk-Tonderys J, Szopa M, Dobrzyński M, Gamian A. Zastosowanie wysokich dawek tokoferolu w prewencji i potencjalizacji działania dioksyn w doświadczalnym zapaleniu. Post Hig 2011;65: 143-57.

43. Sato S, Shirakawa H, Tomita S, Ohsaki Y, Haketa K, Tooi O, et al. Low-dose dioxins alter gene expression related to cholesterol biosynthesis, lipogenesis, and glucose metabolism through the aryl hydrocarbon receptormediated pathway in mouse liver. Toxicol App Pharmacol 2008;229(1): 10-9.

44. Stohs SJ. Oxidative stress induces by 2,3,7,8-tetrachlorodibenzo-p-dioxin (TCDD). Free Radic Biol Med 1990;9(1):79-90. 
45. Całkosiński I, Borodulin-Nadzieja L, Wasilewska U, Stańda M, Majda J, Cegielski M, et al. Wpływ dioksyn na procesy rozrodcze u szczurów w badaniach in vivo. Adv Clin Exp Med 2004;13(6):885-90.

46. Biernacki B, Bulenger K, Woźniak A, Gawlik B, Krasucka D. Czynniki antropogeniczne a układ endokrynny. Życie Weterynaryjne 2015;90(11):720-4

47. Burleson GR, Lebrec H, Yang YG, Ibanes JD, Pennington KN, Birnbaum LS Effect of 2,3,7,8-tetrachlorodibenzo-p-dioxin (TCDD) on influenza virus host resistance in mice. Fundam Appl Toxicol 1996;29(1):40-7.
48. Kerkvliet NI, Steppan LB, Brauner JA, Deyo JA, Henderson MC, Tomar $\mathrm{RS}$, et al. Influence of the Ah locus on the humoral immunotoxicity of 2,3,7,8-tetrachlorodibenzo-p-dioxin: Evidence for Ah-receptor-dependent and Ah-receptor-independent mechanisms of immunosuppression. Toxicol Appl Pharmacol 1990;105(1):26-36.

49. Rosińczuk J, Dymarek R, Całkosiński I. The protective action of tocopherol and acetylsalicylic acid on the behavior of rats treated with dioxins. Adv Clin Exp Med 2018;27(1):5-14. 